\title{
PENGARUH PENGGUNAAN MODAL TERHADAP TINGKAT EFISIENSI YANG DI CAPAI OLEH BANK YANG GO PUBLIK DI BURSA EFEK JAKARTA
}

\author{
Oleh: \\ Yanti \\ Staff PT. Bank Negara Indonesia (Persero) Tbk Syariah, Balik Papan \\ E-mail/No. Hp: - /081334859399
}

\begin{abstract}
Purpose of this research is to know development of legal capital and level of efficiency which in reached by Bank which Go Public at Bursa Effect Jakarta and know legal capital influence to level of efficiency pads Bank which Go Public at Bursa Effect Jakarta. From result of panel data analysis shows CAR and LDR to have influence which are positive with level of efficiency. Test Result $F$ indicates that dependent variables tied is good in simulation influential significant to level of efficiency and tee test result indicates that usage variable of legal capital which in the form of LDR partially had an effect on significant to level of efficiency.
\end{abstract}

Keywords: legal capital, BEJ

\section{PENDAHULUAN}

Salah satu tujuan didirikannya suatu perusahaan adalah mencapai laba, walaupun laba bukanlah satu-satunya tujuan yang harus dicapai. Namun karena alasan bahwa perusahaan harus memberikan imbalan kepada karyawan yang berupa gaji/upah dan memberikan keuntungan kepada pihak-pihak yang telah menanamkan dana (para pemegang saham) pada perusahaan, dan juga perusahaan yang memperhitungkan keuntungan yang didapat dari operasinya untuk kelangsungan hidup perusahaan itu sendiri.

Bentuk pengelolaan dan alokasi modal kerja guna menacapai laba bergantung pada jenis perusahaan yang bersangkutan. Khususnya bank, selain menghimpun keuntungan dari ekspansi kreditnya, bank juga dapat memperoleh tambahan-tambahan dari berbagai alokasi modal, misalnya: pemberian pinjaman dana kepada bank lain, penanaman dana dalam bentuk surat- surat berharga, penyertaan modal pada perusahaan lain dan lain-lain. Semua usaha tersebut dilakukan pengelola perusahaan tidak hanya semata-mata untuk menambah perolehan jumlah laba, namun hal tersebut dilakukan untuk memfungsikan semua modal yang ada, agar modal yang sudah berhasil dihimpun tidak sia-sia.

Modal merupakan faktor yang penting bagi bank dalam rangka pengembangan usaha yang sehat dan dapat menampung resiko kerugian, maka para pemilik dan pengurus bank senantiasa harus menyesuaikan rencana ekspansinya dalam batas-batas tertentu yang dapat ditampung oleh permodalan bank. Disamping itu, pengurus bank selalu melakukan pemantauan terhadap kondisi permodalan banknya sesuai dengan ketentuan dengan cara menghitung sendiri kecukupan permodalannya sekurang-kurangnya untuk periode bulanan dengan menggunakan data yang sesuai dengan 
laporan bulanan yang disampingkan kepada bank Indonesia.

Besarnya jumlah modal bank yang harus dimiliki umumnya ditentukan oleh penguasa moneter. Bank Sentral sebagai penguasa moneter menetapkan jumlah minimum modal yang harus dipenuhi oleh setiap bank, yang biasanya dihubungkan dengan total asetnya setelah memperhitungkan resiko yang mungkin dihadapi masing-masing asset. Ketentuan minimum permodalan tersebut biasanya penggunaan suatu ukuran yang disebut Capital Adequacy Ratio (CAR) atau ratio kecukupan modal, yang dihitung dengan memperbandingkan antara jumlah modal yang dimiliki dengan total aktiva tertimbang menurut resiko (ATMR).

Oleh karena itu dengan modal yang cukup bisa diharapkan perusahaan dapat memperoleh profitabilitas yang tinggi dan mampu melakukan kewajiban likuiditasnya. Daya tarik bagi pemilik perusahaan (pemegang saham) dalam suatu perseroan adalah profitabilitas. Profitabilitas berarti hasil yang diperoleh melalui usaha manajemen atas dana yang diinvestasikan pemilik. Pemilik juga tertarik pada pembagian laba yang menjadi haknya yaitu seberapa besar banyak yang diinvestasikan kembali dan seberapa banyak yang dibayarkan sebagai deviden kepada mereka.

Profitabilitas juga merupakan alat untuk mengukur efektifitas bank memperoleh laba, disamping dapat dijadikan sebagai ukuran kesehatan keuangan. Sedangkan likuiditas mengacu kepada kemapuan bank menyediakan dana dalam jumlah yang cukup, tepat pada waktunya untuk memenuhi kewajiban-kewajibanya (Erich 1997:86).

Seperti telah diketahui bahwa jasa utama bank adalah menrima dana simpanan dari masyarakat dan kemudian menyalurkan kembali dana tersebut pada pihak-pihak yang membutuhkan dana. Apabila dana simpanan yang berhasil dihimpun tidak seimbang dengan jumlah dana yang dapat disalurkan (lebih banyak dana yang berhasil dihimpun), maka bank akan mengalami kerugian, sebab bank harus memberikan imbalan bunga kepada pihak penyimpanan dana tersebut. Oleh karena itu untuk mengantisipasi modal yang tidak termanfaatkan tersebut, maka bank dapat mengalokasikan dalam bentuk yang lain yang dapat menghasilkan keuntungan atau setidaknya pulang pokok (tidak untung tidak rugi).

Pada dasarnya masyarakat menilai suatu perusahaan itu berhasil atau tidak dalam operasionalnya adalah dari besar kecilnya keuntungan yang mampu diperoleh. Apabila suatu perusahaan mampu memperoleh keuntungan yang cukup dalam periode tertentu maka dapat dikatakan bahwa perusahaan tersebut sukses. Dan sebaliknya perusahaan itu tidak mampu menghasilakan keuntungan dari operasinya maka perusahaan tersebut dikatakan merugi atau tidak berprospek. Oleh karena itu keberhasilan dari perusahaan yang ditunjukkan dengan pencapaian laba yang besar sangat dipengaruhi oleh peran manajemen perusahaan dalam mengelola dan mengalokasikan modal.

Kepandaian manajemen perusahaan dalam melihat kondisi perekonomian dan kondisi lingkungan usaha (masyarakat) sangat menentukan keberhasilan perusahaan. Misalkan perekonomian sedang terpuruk seperti sekarang ini, dimana tingkat suku bunga tinggi (akibat kebijakan uang ketat) dan banyak industri yang pailit, maka perusahaan bank tidak dapat mengandalkan memperoleh keuntungan dari ekspansi kredit dan penyetoran modal. Namun perusahaan dapat mengalokasikannya ke tempat yang lebih aman meskipun keuntunga yang 
didapat relatif kecil yaitu berupa pembelian Sertifikat Bank Indonesia (SBI).

Pengelolaan modal guna mencapai laba yang maksimal hampir dilakukan oleh seluruh perusahaan. Namun hal yang lebih pentig dari itu adalah pengelolaan modal guna mempertahankan kinerja perusahaan agar tidak jatuh pailit. Berbagai kasus akhir-akhir ini menunjukkan bahwa orientasi penggunaan/pengelolaan modal untuk mencapai laba yang maksimal tanpa memperhatikan kondisi ekonomi menimbulkan banyak perusahaan yang jatuh pailit. Misalkan bank-bank yang terlikuidasi (Bank Bali), dalam kondisi ekonomi yang sulit, dimana lapangan usaha tidak memiliki prospek, bank Bali masih tetap mengandalkan ekspansi kreditnya guna mencapai laba (memperhatikannya kinerjanya), hal ini ditunjukkan dengan jumlah kredit yang disalurkan semakin meningkat (besar).

Semakin besarnya kredit yang disalurkan bank Bali semakin memperbesar jumlah kredit macet yang ada. Dan karena ekspansi kredit tersebut banyak menggunakan dana pinjaman pula, maka Bank Bali akhirnya terbelit banyak hutang yang akhirnya bank ini tidak mampu memenuhi berbagai ketentuan dari pemerintah, yang dampak akhirnya di tutup. Masalah yang akan dibahas dalam skripsi dapat dirumuskan adalah 1) Bagaimana perkembangan modal dan tingkat efisiensi Bank yang Go publik di Bursa Efek Jakarta. 2) Seberapa besar pengaruh modal yang dimiliki terahadap tingkat efisiensi yang dicapai oleh Bank yang Go publik di Bursa Efek Jakarta.

\section{TINJAUAN PUSTAKA}

Setiap kegiatan usaha, baik perusahaan industri maupun perbankan membutuhkan modal untuk membelanjai operasinya sehari-hari, misalkan untuk membayar upah buruh, gaji pegawai dan sebagainya dimana uang atau dana yang telah dikeluarkan itu diharapkan akan kembali masuk kedalam perusahaan dalam waktu yang secepatnya.

Setiap bank untuk melaksanakan aktivitas tidak akan terlepas dari kebutuhan akan sejumlah dana guna membelanjai harta lancar dan harta tetap. Kebutuhan dana tersebut dapat dipenuhi dengan menggunakan modal sendiri, pinjaman jangka pendek maupun jangka menegah.

Menurut Riyanto (1992:51) menyebutkan tiga konsep atau definisi modal yang umum dipergunakan yaitu:

Modal menurut konsep kuantitatif adalah keseluruhan dari aktiva lancar yang sering disebut modal kerja bruto, dimana aktivita ini merupakan aktiva yang sekali berputar kembali dalam bentuk semula atau aktiva dimana dan yang ditanamkan didalamnya akan dapat bebas lagi dalam waktu yang pendek.

Dengan demikian menurut konsep ini keseluruhan dari pada aktiva lancar. Modal dalm pengertian ini sering disebut modal kerja bruto (Groos Working Kapital).

Apabila kuantitatif modal hanya dikaitkan dengan besarnya besar aktiva lancar saja, maka pada konsep kualitatif ini pengertian modal juga dikaitkan dengan besarnya jumlah hutang lancar atau hutang yang harus segera dibayar. Maka sebagian dari aktiva lancar ini harus disediakan untuk memenuhi kewajiban finansial yang harus segera dibayar, dimana bagian aktiva ini tidak boleh dipergunakan membiayai operasi perusahaan untuk menjaga likuiditasnya.

Oleh karena itu modal menurut konsep ini sebagian dari aktiva lancar yang benar-benar dapat dipergunakan untuk membiayai operasi perusahaan tanpa mengganggu likuiditasnya. Modal menurut konsep ini adalah kelebihan aktiva lancar di atas hutang lancarnya 
atau sebagian dari aktiva lancar benarbenar dapat dipergunakan untuk membiayai operasi tanpa mengganggu likuiditasnya, modal dalam pengertian ini sering disebut modal kerja netto (Net Working Kapital).

Konsep fungsional mendasarkan pada fungsi dari pada dana dalam mengahasilkan pendapatan (Income). Setiap dana yang akan dikerjakan atau digunakan dalam perusahaan adalah dimaksudkan untuk mendapatkan pendapatan. Ada bagian dana lain yang digunakan dalam suatu periode akuntansi tertentu yang seluruhnya langsung menghasilkan pendapatan bagi periode tersebut (Current Income) dan ada sebagian dana lain yang juga dipergunakan selama periode tersebut tetapi tidak seluruhnya digunakan untuk menghasilkan current income. Sebagian dari dana ini dimaksudkan untuk menghasilkan pendapatan untuk periodeperiode berikutnya.

Dari ketiga konsep tersebut diatas penulis dapat menarik kesimpulan bahwa yang dimaksud dengan "modal adalah net working capital atau kelebihan aktiva lancar terhadap hutang lancar, sedang untuk modal sebagai aktiva lancar digunakan istilah modal kerja bruto (Grooss Working Capital)".

Menurut Taswan (1997:144) modal merupakan kewajiban kepada pemilik, karena modal adalah bagian hak pemilik bank yang dapat diketahui dari selisih antara aktiva dengan kewajiban (pihak luar). Dengan demikian modal bukanlah ukuran nilai jual perubahan atau bank, sebagai kewajiban ke pihak pemilik. Maka modal dapat berkurang atau bertambah tergantung dari penarikan ataupun penambahan dari pemilik modal.

Menurut Dahlan Siamat (1993:56) modal adalah dana yang diinvestasikan oleh pemilik dalam rangka pendirian badan usaha yang dimaksudkan untuk membiayai kegiatan usaha bank disamping memenuhi peraturan yang ditetapkan.

Menurut Edward W.Reed dan Edward K.Gill (1995:138) Fungsi modal bank adalah pertama, Fungsi Perlindungan. Karena tingginya prosentase asset bank yang dibiayai oleh pemegang deposit sekitar $80 \%$. Fungsi utama jumlah modal saham yang terbatas dianggap sebagai pelindung terhadap penabung. Selain fungsi penting ini, modal bank mengurangi resiko yang dipikul oleh Federal Deposit Insurance Corporation dan pemegang saham bank. Fungsi pelindung dianggap tidak hanya sebagai pembayaran terhadap penabung dalam hal likuiditas, tetapi juga sebagai pendukung solvabilitas dengam memberikan penyangga dalam bentuk kelebihan asset, sehingga bank tidak terancam kerugian dapat terus melakukan kegiatan.

Kedua, Fungsi operasional bank dianggap sekunder dibandingkan dengan perusahaan bukan bank. Fungsi operasional meliputi antara lain penyediaan dana untuk pembelian tanah, gedung, mesin-mesin dan perlengkapan serta menyediakan penyangga untuk menyerap kerugian operasi yang kadangkadang terjadi.

Ketiga, Fungsi Pengatur. Selain menyediakan basis untuk operasi dan perlindungan penabung, fungsi ini timbul karena kepentingan khusus masyarakat luas dalam operasi perusahaan perbankan yang berhasil dan Undang-Undang dan peraturan yang memungkinkan instansi pemerintah untuk melakukan pengawasan terhadap operasi ini. Peraturan yang berkaitan dengan modal bank mencakup peraturan yang berkaitan dengan persyaratan minimum yang diperlukan untuk memperoleh izin untuk mendirikan 
cabang dan membatasi pinjaman bank, investasi dan pengambilalihan.

Faktor-faktor yang dipertimbangkan dalam menilai kecukupan modal adalah Pertama, Kualitas manajemen bank yang bersangkutan apabila suatu Bank dipimpin / dikelola oleh suatu kelompok manajemen yang berkualitas tinggi yang ditinjau dari berbagai aspek, maka hasilnya akan berlainan dengan bank yang dikelola oleh suatu kelompok manajemen yang berkualitas rendah dan tidak kompak.

Kedua, Tingkat Likuiditas yang dimilikinya. Suatu bank yang memiliki alat-alat likuid yang sangat terbatas dalam memenuhi kewajibankewajibannya, akan ada kemungkinan penyediaan likuiditas tersebut akan diambil dari permodalannya. Dengan demikian akan dirasakan oleh Manajemen Bank yang bersangkutan betapa terbatasnya modal yang dimiliki oleh bank.

Ketiga, Tingkat Kualitas Assets Suatu bank yang banyak memiliki debitur dan non earning assets lainnya yang kurang produktif maka sudah dapat dipastikan bank tersebut tidak dapat melaksanakan kewajibannya secara lancar.Dan sebaliknya bagi bank yang mempunyai earning assets yang memadai maka kebutuhan modalnya akan dapat diperoleh dari laba usah bank yang bersangkutan,yang akan berkembang secara komulatif. Dan sebaliknya apabila bank tersebut rugi terus-menerus maka akan ada kemungkinan pula modalnya akan terkikis sedikit demi sedikit.

Keempat, Struktur Deposito apabila bank memperoleh dana sebagian besar berupa deposito berjangka dan dana-dana mahal lainnya, tentu akan menimbulkan pula biaya yang tinggi.

Kelima, Tingkat Kualitas dari Sistem dan Prosedurnya. Sistem dan operating prosedure suatu bank yang baik tentu akan menunjang kegiatan usaha bank yang bersangkutan pada tingkat efisiensi yang tinggi. Dengan efisiensi yang tinggi ini akan memungkinkan bank untuk memperoleh laba yang akan memperkuat capital dari bank yang bersangkutan. Sebaliknya bagi bank yang beroperasi dengan biaya yang tinggi ada kemungkinan biaya yang tidak tertutup oleh penghasilan akan menjadi beban capital.

Keenam, Tingkat Kualitas dan Karakter Para Pemilik Saham. Para pemilik saham yang berorientasi ke masa depan bank yang dimilikinya agar lebih baik dikemudian hari tentu akan berusaha membentuk akumulasi modal secara maksimal hingga capital/modal bank yang bersangkutan tentu tidak akan mengalami perkembangan.

Ketujuh, Kapasitas Untuk Memenuhi Kebutuhan Keuangan Jangka Pendek Maupun Jangka Panjang.

Kedelapan, Riwayat Pemupukan Modal dan Peraturan Pembagian Laba yang diperolehnya.

Pada bank-bank pemerintah telah ditetapkan tata cara pembagian laba yang diperolehnya tiap tahun secara pasti, tentu tidak ada keleluasaan lagi bagi bank yang bersangkutan dalam memupuk modalnya sesuai dengan keinginan maupun kebutuhan investasi pengembangan bank tersebut di kemudian hari.

Menurut Muljono(1996:435), besarnya rentabilitas usaha suatu bank antara lain juga dipengaruhi oleh tingkat efisiensi yang ada, oleh karena itu jika rentabilitas yang ada itu rendah, maka perlu diadakan pengukuran efisiensi yang ada. Rasio efisiensi usaha digunakan untuk mengukur kinerja manajemen suatu bank dalam menggunakan semua factor produksinya dengan tepat guna dan hasil guna. Rasio yang dapat digunakan yaitu: 
Net Interest Margin (NIM) Adalah kemampuan manajemen bank dalam memanfaatkan aktiva yang dimiliki guna menghasilkan pendapatan bunga setelah dikurangi dengan biaya bunga.

Biaya Operasional dengan Pendapatan Operasional (BO/PO) adalah untuk mengukur kinerja manajemen suatu bank dalam menggunakan semua faktor produksinya dengan tepat guna dan hasil guna.

Leverage Multiplier Ratio adalah mengelola aktiva yang dimiliki mengingat biaya yang dikeluarkan dalam mengelola aktiva.

Cost of Fund adalah membayar biaya bunga dibanding rata-rata dana yang dimiliki.

Cost of Money adalah untuk mengetahui besarnya rata-rata keseluruhan biaya yang dikeluarkan bank dalam penghimpunan dana.

Keterkaitan CAR dan BO/PO karena dalam system dan operating prosedur suatu bank yang baik tentu akan menunjang kegiatan usaha bank yang bersangkutan pada tingkat efisiensi yang tinggi. Dengan efisiensi yang tinggi ini akan memungkinkan bank untuk memperoleh laba yang akan memperkuat capital dari bank yang bersangkutan.

Sebaliknya bagi bank yang beroperasi dengan biaya yang tinggi ada kemungkinan biaya yang tidak tertutup oleh penghasilan akan menjadi beban kapital atau mengurangi besarnya kapital rasio. Misalnya dana pihak ketiga, biaya tenaga kerja,dan biaya rupa-rupa yang terdiri dari premi asuransi/jaminan kredit/sewa gedung kantor/biaya pemeliharaan/perbaikan gedung kantor dan lain-lain.

Di dalam penelitian ini rasio-rasio keuangan yang dipergunakan adalah CAR digunakan untuk mengukur kemampuan permodalan yang ada pada suatu bank untuk menutup kemungkinan kerugian di dalam kegiatan perkreditan. Sesuai dengan standar BI, setiap bank diharapkan mempunyai CAR $8 \%$ karena dengan penyediaan modal yang cukup memungkinkan bank meneruskan operasinya tanpa terganggu. Rasio ini dirumusksan sebagai berikut:

$\mathrm{CAR}=\frac{\text { Aktiva Tertimbang Menurut Resiko }}{\text { BO/PO digunakan untuk }}$ mengetahui berapa besar pendapatan operasional yang dapat dimanfaatkan bank agar dapat menekan / meminimalkan biaya operasional, sehingga dapat memberikan gambaran efisiensi suatu bank dengan kata lain dapat digunakan untuk mengukur kinerja manajemen suatu bank dalam menggunakan semua factor produksinya dengan tepat guna dan hasil guna. Dalam rangka penilaian kesehatan bank umum (Metode CAMEL), BI memberi nilai bobot sebesar $5 \%$ untuk rasio $\mathrm{BO} / \mathrm{PO}$. Karena beban operasional yang kecil akan meningkatkan pendapatan Operasional suatu bank. Sehingga bank memiliki efisiensi yang baik. Rasio ini dirumuskan sebagai berikut:

$$
\mathrm{BO} / \mathrm{PO}=\frac{\text { Beban Operasional }}{\text { Pendapatan Operasional }}
$$

ROE adalah perbandingan antara laba bersih dengan modal sendiri. ROE ini merupakan indikator yang penting bagi para pemegang saham dan calon investor untuk mengukur kemampuan bank dalam memperoleh laba bersih yang terkait dengan pembiayaan deviden. Sesuai standar BI, angka ROE terbaik adalah $11 \%$. Rasio ini dirumuskan sebagai berikut:

Laba bersih setelah pajak $\mathrm{ROE}=\frac{\text { Modal Sendiri }}{\text { M }}$ 
Laba bersih setelah pajak dapat diperoleh dalam laporan rugi laba yang disebut dengan laba tahun berjalan (laba yang diperoleh dalam tahun buku berjalan setelah dikurangi taksiran utang pajak). Sedangkan modal sendiri dapat diperoleh dari jumlah ekuitas laporan neraca bank.

Menurut ketentuan Bank Indonesia (SK.No.30/11 KEP/DIR dan SE.No.30/2/UPPBB tanggal 19 Maret 1998) Tingkat kesehatan Bank pada dasarnya dinilai dengan pendekatan kualitatif atas berbagai aspek yang berpengaruh terhadap kondisi dan perkembangan suatu bank. Pendekatan kualitatif tersebut dilakukan dengan menilai faktor permodalan, kualitas aktiva, manajemen, rentabilitas / profitabilitas dan likuiditas (CAMEL). Penekanan mengenai pentingnya suatu usaha bank menjaga tingkat kesehatannya juga diatur dalam UU No.7 tahun 1997 bab V pasal 29 tentang pembinaan dan pengawasan, yaitu pada ayat 2:

"Bank wajib memelihara tingkat kesehatan bank sesuai dengan ketentuan kecukupan modal, kualitas asset, kualitas manajemen, likuiditas, rentabilitas, solvabilitas dan aspek lain yang berhubungan dengan usaha bank dan wajib melakukan kegiatan usaha sesuai dengan prinsip kehati-hatian".

Sedangkan menurut Achwan (1986:39) berdasarkan SK Direksi BI No.10/163/KEP/DIRUPPB dan SE BI No.10/5/UPPB tanggal 31 Agustus 1997 dan disempurnakan SK Direksi BI No.23/81/KEP/DIR dan SE BI No.23/21/BPPP tanggal 28 Februari 1991, faktor-faktor yang dinilai dalam penentuan kesehatan bank terdiri dari 3 kelompok yaitu keadaan keuangan, kualitas aktiva produktif dan tata kerja serta kepatuhan terhadap ketentuan yang berlaku. Kelompok keadaan keuangan terdiri dari tiga faktor penilaian yaitu likuiditas, rentabilitas, dan solvabilitas. Dan analisa keuangan dapat dilakukan dengan melihat perhitungan rasio efisiensi dan profit bank.

Menurut Lukman Syamsudin dalam bukunya Manajemen Keuangan menyatakan bahwa pentingnya rasio efisiensi dan profitabilitas,

karena ini akan memberikan informasi yang sangat penting bagi lajunya perusahaan dalam jangka pendek.

Dalam memenuhi kebutuhan dana, suatu perusahaan harus mengadakan pertimbangan antara berbagai faktor, misalnya antara efisiensi dan profitabilitas. Profitabilitas merupakan alat untuk mengukur tingkat keuntungan operasi perusahaan dan dalam menentukan keuntungan ini jelas berhubungan dengan pengelolaan yang ada didalam perusahaan terhadap modal. Sebab bila ini terjadi akan mengganggu efisiensi perusahaan dan begitu juga sebaliknya. Namun perusahaan jangan terlalu berlebihan dalam menyediakan modal, karena itu menyebabkan modal tertanam dan tidak produktif. Jadi jelas disini bahwa dalam usaha perusahaan itu diperlukan adanya pengelolaan dana yang efisien, sehingga pada akhir periode akan didapatkan tingkat profitabilitas yang tinggi, maka aktivitas perusahaan dapat terjamin. Demikian pula dalam pemenuhan likuiditas, apabila hanya didasarkan pada pertimbangan likuiditasnya maka semakin panjang umur kredit yang ditarik maka makin baik. Karena makin panjang kesempatan untuk memperoleh aliran kas masuk dan berarti makin besar kemampuan untuk membayar kembali hutangnya. Tetapi dipihak lain ditinjau dari sudut profitabilitas, pembiayaan modal dengan kredit jangka panjang akan memperbesar biaya, karena ada waktu atau periode dimana dana yang 
dipinjam akan menganggur, sedangkan perusahaan tetap membayar bunganya. Dengan demikian harus diadakan keseimbangan antara tujuan efisiensi dan profitabilitas.

\section{METODE PENELITIAN}

Tahapan dalam metode analisa yang digunakan dalam penelitian ini adalah sebagai berikut:

$\mathrm{CAR}=$

$\frac{\text { ModalBank }}{\text { AktivitaTertimbangMenurutresiko(ATMR) }} \times 100 \%$

$\mathrm{ROE}=\frac{\text { LabaBersihSetelahPajak }}{\text { ModalSendiri }} \times 100 \%$

$(\mathrm{BO} / \mathrm{PO})=\frac{\text { BebanOperasional }}{\text { Pendapa } \tan \text { Operasional }} \times 100 \%$

Untuk mengetahui pengaruh variabel bebas terhadap variabel terikat (Y), maka digunakan analisis dengan metode regresi data panel dengan menggunakan bantuan program eviews basic. Dan diformulasikan sebagai berikut:

$\operatorname{In} Y_{\text {it }}=\beta_{0}+\beta_{1 x i t}+\beta_{2 i x t}+$ eit

Dimana, $Y_{i t}=$ Efisiensi; $\mathrm{t}=$ Waktu; $\beta=$ Konstanta; X1= Kecukupan Modal;

$\mathrm{X} 2=$ Profit; $\mathrm{e}=$ Kesalahan pengganggu (Error); $\mathrm{i}=$ Jenis Perusahaan.

Dalam data panel ada 3 tehnik yang digunakan yaitu tehnik common effect, fixed effect dan random effect, sehingga untuk menentukan tehnik mana yang tepat maka harus melalui 3 uji yaitu uji LM, uji F dan uji Hausman.

Ada 3 tehnik yang biasa digunakan untuk mengestimasi regresi dengan data panel yaitu: pertama, Common effects.

In $Y_{i t}=\beta_{0}+\beta_{1} x_{i t}+\beta_{2 i t} x_{2 t}+e_{i t}$

Command effect dianggap mempunyai intercep dan slope yang sama. Dalam data panel tehnik common effect tidak memperhatikan memperhatikan dimensi individu atau waktu, intercep yang sama baik antar waktu maupun antar perusahaan menyebabkan jauh dari realita kondisi sampel. Contoh, mungkin ada perbedaan manajemen atau penggajian antar perusahaan sehingga cara mudah untuk melihat perbedaanya adalah melihat residualnya atau di buat slope sama intercept berbeda.

Kedua, Fixed Effect.

Rumus $=$ In $Y_{i t}=\beta_{0 \mathrm{i}}+\beta_{1} X_{1 i t}+\beta_{2 i} \mathrm{t}$ $\mathrm{X}_{2 \mathrm{t}}+\mathrm{e}_{\mathrm{it}}$

Dalam metode fixed effect ada penambahan variabel dummy untuk menjelaskan perbedaan intersep. Model estimasi ini disebut dengan tehnik LSDV (least square dummy variabel) . fixed effects melalui LSDV menunjukkan ketidak pastian model, yang biasa digunakan untuk mengatasi masalah tersebut menggunakan variable residual dikenal sebagai metode random effects, dimana residual kemungkinan ada korelasi antar waktu maupun antar individu.

Ketiga, Random effects.

In $Y_{i t}=\beta_{0 \mathrm{i}}+\beta_{1} X_{1 i t}+\beta_{2 \mathrm{i}} \mathrm{t} \mathrm{X}_{2 \mathrm{t}}+\mathrm{e} \mathrm{e}_{\mathrm{it}}$

Dalam tehnik random effects memiliki asumsi yang sama dengan fixed effect yaitu intercep berbeda dan slope sama akan tetapi diasumsikan bahwa intercept adalah yang random atau skokastik. Model ini sangat berguna jika individu perusahaan yang kita ambil sebagai sampel dipilih secara random.

Dasar pengambilan keputusan untuk pengujian hipotesis yang diajukan adalah Jika LM hitung $\leq$ Tabel chi square dengan taraf signifikansi $\alpha=5 \%$, maka $\mathrm{H}_{0}$ diterima atau menolak $\mathrm{H}_{\mathrm{a}}$ yang berarti bahwa model common effects (intercept dan slope sama) merupakan model yang tepat. Jika LM hitung $\geq$ Tabel chi square dengan taraf signifikansi $\alpha=5 \%$, maka $\mathrm{H}_{\mathrm{a}}$ diterima atau menolak $\mathrm{H}_{0}$ yang berarti bahwa 
model Random effects (intercept berbeda dan slope sama) merupakan model yang tepat.

$$
\begin{aligned}
& \text { Rumus }=\mathrm{LM}= \\
& \frac{n T}{2(T-1)}\left[\frac{\sum_{i=1}^{n}\left[\sum_{t=1}^{T} e_{i t}\right]}{\sum_{i=1}^{n} \sum_{t=1}^{T} e^{2} i t}-1\right]^{2} \\
& = \\
& \frac{n T}{2(T-1)}\left[\frac{\sum_{i=1}^{n}\left(T \bar{e}_{i}\right)^{2}}{\sum_{i=1}^{n} \sum_{t=1}^{T} e^{2}{ }_{i t}}-1\right]^{2}
\end{aligned}
$$

Keterangan:

n : Jumlah Individu

$\mathrm{T} \quad$ : Jumlah Periode

e $\quad$ : Residual metode OLS

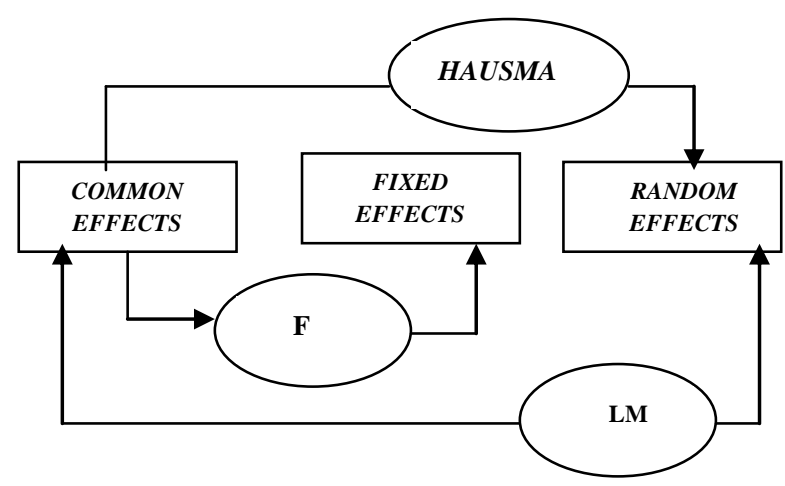

Gambar 1. Alur Pengujian pemilihan model dalam pengolahan data panel

Dalam tehnik estimasi data panel ini ada 3 tehnik yang digunakan yaitu tehnik common effects, tehnik fixed effect dan tehnik random effect. Untuk mengetahui tehnik apa yang sebaiknya dipilih untuk regresi data panel, maka akan ada beberapa pengujian yang harus dilakukan, pengujian ini di gunakan untuk memilih tehnik yang paling tepat dalam penelitian..
Pertama, Uji statistik F digunakan untuk memilih antara metode OLS tanpa variabel dummy atau fixed effect.

Kedua, Uji langrage multiplier (LM) digunakan untuk memilih antara OLS tanpa variabel dummy atau random effect.

Ketiga, Uji Hausman digunakan untuk memilih antara fixed effect atau random effect.

\section{PEMBAHASAN}

Uji Langrange Multiplier (LM) digunakan untuk memilih antara OLS tanpa variable dummy atau random effects. Uji LM digunakan untuk mengetahui apakah model random effects lebih baik dari metode OLS. Uji signifikansi model random effects didasarkan pada nilai residual dari OLS. Hipotesis:

$\mathrm{H}_{0}$ : OLS tanpa variable dummy (intersep dan slope sama) common effects

$\mathrm{H}_{\mathrm{a}} \quad$ : Random Effects

Dasar pengambilan keputusan untuk pengujian hipotesis yang diajukan adalah sebagai berikut:

Jika LM hitung $\leq$ Tabel chi square dengan taraf signifikansi $\alpha=5 \%$, maka $\mathrm{H}_{0}$ diterima atau menolak $\mathrm{H}_{\mathrm{a}}$ yang berarti bahwa model commans effects (intercept dan slope sama) merupakan model yang tepat.

Jika LM hitung $\geq$ Tabel chi square dengan taraf signifikansi $\alpha=5 \%$, maka $\mathrm{H}_{\mathrm{a}}$ diterima atau menolak $\mathrm{H}_{0}$ yang berarti bahwa model Random effects (intercept berbeda dan slope sama) merupakan model yang tepat.

$$
\mathrm{LM}=\frac{n T}{2(T-1)}\left[\frac{\sum_{i=1}^{n}\left[\sum_{t=1}^{T} e_{i t}\right]}{\sum_{i=1}^{n} \sum_{t=1}^{T} e^{2} i t}-1\right]^{2}
$$




$$
=\frac{n T}{2(T-1)}\left[\frac{\sum_{i=1}^{n}\left(T \bar{e}_{i}\right)^{2}}{\sum_{i=1}^{n} \sum_{t=1}^{T} e_{i t}^{2}}-1\right]^{2}
$$

Keterangan:

n : Jumlah Individu

$\mathrm{T}$ : Jumlah Periode

e : Residual metode OLS

Uji statitik $F$ yang digunakan untuk memilih antara metode OLS tanpa vaiabel dummy (common effects) dengan fixed effects diketahui:

$\mathrm{n}: 21$

$\mathrm{T}: 3$

E : 15081.73

Rumus

$$
\begin{gathered}
=\frac{n T}{2(T-1)}\left[\frac{\sum_{i=1}^{n}\left[\sum_{t=1}^{T} e_{i t}\right]}{\sum_{i=1}^{n} \sum_{t=1}^{T} e^{2} i t}-1\right]^{2} \\
=\quad\left[\frac{\sum_{i=1}^{n}\left(T \bar{e}_{i}\right)^{2}}{\sum_{i=1}^{n} \sum_{t=1}^{T} e^{2}}-1\right]^{2} \\
\left.\frac{n T}{2(T-1)}\right] \\
=\quad\left[\frac{227458579,8}{15081.73}-1\right]^{2} \\
\frac{21.3}{2(3-1)}\left[\frac{15.75[227428417.3]}{}\right. \\
=358.199757
\end{gathered}
$$

Dari hasil perhitungan diperoleh 358.199.757 $\geq 79.0819$ atau LM hitung $\geq$ Tabel chi square dengan taraf signifikansi $\alpha=5 \%$, maka $\mathrm{H}_{\mathrm{a}}$ diterima atau menolak $\mathrm{H}_{0}$ yang berarti bahwa model Random effects (intercept berbeda dan slope sama) merupakan model yang tepat.

Uji Hausman digunakan untuk memilih antara Fixed effects atau Random effects. Uji Hausman ini digunakan jika metode fixed effects dan random effects lebih baik dari metode
OLS, maka untuk menentukan model mana yang dipilih adalah menggunakan uji Hausman.

Uji Hausman ini didasarkan pad ide bahwa LSDV di dalam metode fixed effects dan GLS adalah efisien sedangkan metode OLS tidak efisien. Dilain pihak alternatifnya metode OLS efisien dan GLS tidak efisien. Oleh karena itu uji hipotesis nulnya adalah hasil keduanya tidak berbeda sehingga uji hausman bisa dilakukan berdasarkan perbedaan estimasi tersebut.

Hipotesis:

$\mathrm{H}_{0} \quad$ : Random effects

$\mathrm{H}_{\mathrm{a}} \quad$ : Fixed effects

Dasar pengambilan keputusan untuk pengujian hipotesis yang diajukan adalah sebagai berikut a.) Jika Hausman hitung $\leq$ Tabel chi square dengan taraf signifikansi $\alpha=5 \%$, maka $\mathrm{H}_{0}$ diterima atau menolak $\mathrm{H}_{\mathrm{a}}$ yang berarti bahwa model Random effects (intercept berbeda dan slope sama) merupakan model yang tepat.b.) Jika Hausman $\geq$ Tabel chi square dengan taraf signifikansi $\alpha=5 \%$, maka $\mathrm{H}_{\mathrm{a}}$ diterima atau menolak $\mathrm{H}_{0}$ yang berarti bahwa model fixed effects (intercept berbeda dan slope sama) merupakan model yang tepat. Sumber data terlapir Dari hasil perhitungan diperoleh $0.358567 \leq$ 79.0819 atau LM hitung $\leq$ Tabel chi square dengan taraf signifikansi $\alpha=5 \%$, maka $\mathrm{H}_{0}$ diterima atau menolak $\mathrm{H}_{\mathrm{a}}$ yang berarti bahwa model Random Effect (intercept berbeda dan slope sama) merupakan model yang tepat.

Hasil uji signifikansi model data panel maka Random Effect merupakan metode yang tepat estimasi pengolahan data dengan program eviews basic tersebut dapat dilihat pada tabel.

Dari hasil regresi yang telah dilakukan dapat diketahui bahwa ada pengaruh signifikan antara kecukupan modal terhadap profitabilitas. 


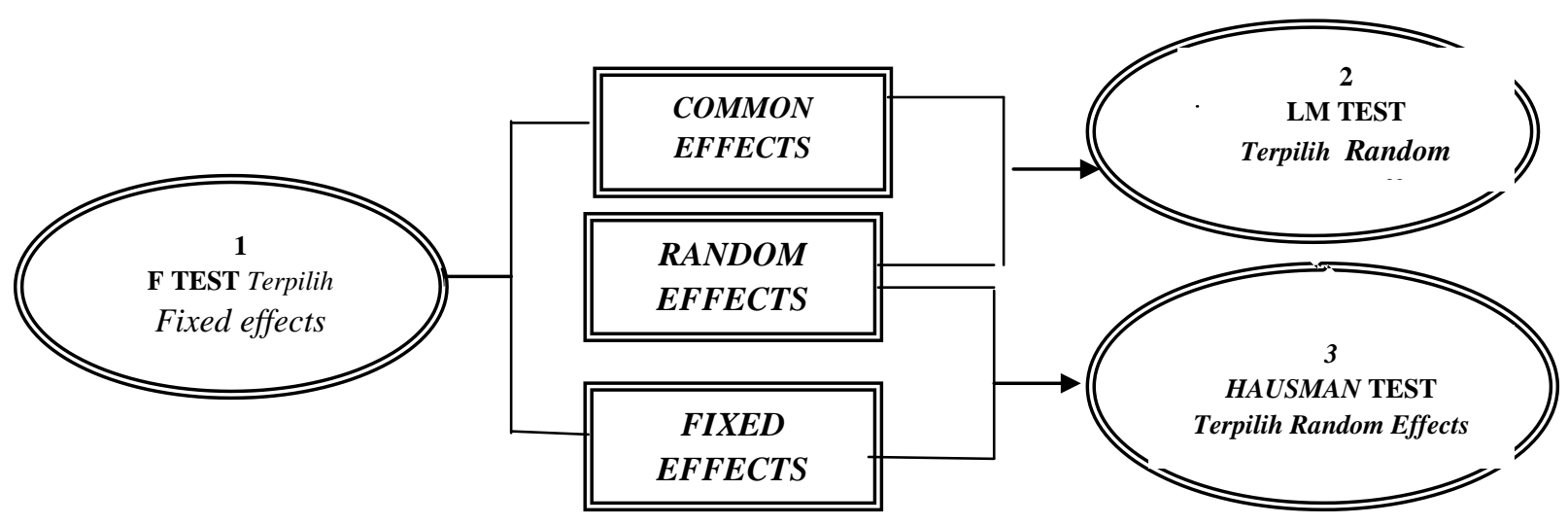

Gambar 2. Hasil Pengujian pemilihan model dalam pengolahan data panel

Dari keseluruhan bank yang digunakan dalam penelitian dapat diketahui bahwa tingkat profit mengalami kenaikan dari tahun 20042006, dan jumlah bank yang mengalami kenaikan sebanyak 15 bank yaitu BNI, BRI, BCA, Danamon, BII, Niaga, Pan Indonesia, Permata, Lippo, Buana Indonesia, Kesawan, Victoria Internasional, Mayapada Internasional, Bumiputera, dan Mandiri.

Sedangkan bank yang mengalami penurunan sebanyak 6 bank yaitu Mega, NISP, Swadesi, Arta Niaga Kencana, Eksekutif Internasional dan Nusantara Parahyangan. Sedangkan tingkat CAR tahun 2006 tertinggi diperoleh Bank Mandiri dengan tingkat rasio $26.31 \%$ dan terendah terdapat pada bank Eksekutif Internasional dengan tingkat CAR 9\%. Nilai Capital Adequacy Rasio (CAR) ini harus berada diatas rata-rata CAR yang ditentukan oleh BI yaitu $\geq$ $8 \%$, namun diusahakan jangan terlalu jauh diatas $8 \%$ karena akan berdampak pada bagian modal yang digunakan untuk berjaga-jaga menjadi terlalu banyak.

Bank Mandiri memiliki nilai CAR yang cukup besar yaitu jauh diatas ketentuan BI. Hal ini menyebutkan bahwa modal Bank Mandiri terlalu banyak yang menganggur dan tidak produktif. Rasio Profitabilitas diperoleh dengan membandingkan laba bersih dan total asset yang dimiliki bank. Sedangkan Rasio kecukupan modal dan Aktiva Tertimbang Menurut Resiko (ATMR). Peningkatan laba secara otomatis juga meningkatkan profitabilitas bank. Di dalam suatu perusahaan dana yang menganggur jangan terlalu besar, karena akan menyebabkan modal tertanam dan tidak produktif. Jadi jelas bahwa didalam suatu usaha diperlukan adanya pengelolaan dana yang efisien sehingga pada akhir perode akan didapat profitabilitas yang tinggi. Perkembangan rasio profitabilitas ditandai dengan naiknya laba dan menyebabkan perkembangan rasio kecukupan modal. Dengan kata lain modal yang cukup dapat meningkatkan profitabilitas yang dihasilkan perusahaan. Hasil estimasi sebelumnya bahwa kecukupan modal dengan profitabilitas berpengaruh positif adalah benar.

Dari hasil estimasi sebelumnya yang telah dilakukan dapat diketahui bahwa antara profitabilitas terhadap efisiensi tidak signifikan atau negatif. Rasio efisiensi dihitung diperoleh dengan membandingkan beban operasional dan beban operasional. Besarnya laba/profit suatu bank antara lain juga dipengaruhi oleh efisiensi yang ada, oleh karena itu jika profit yang ada itu rendah, maka perlu diadakan pengukuran efisiensi yang ada. Informasi 
paling penting yang diperoleh dari laporan rugi laba adalah struktur pendapatan dan biaya / beban, karena informasi ini memberikan gambaran tentang efisiensi sebuah bank. Jika diketahui pendapatan bersih setelah pajak suatu bank >0 (positif), maka bank tersebut dapat dikatakan memperoleh laba. Oleh karenanya, suatu bank diharapkan memiliki pendapatan bersih setelah pajak tinggi yang ditekan dengan biaya operasional yang rendah sehingga hasil perhitungan dari profitabilitas yaitu ROE juga tinggi.

Profitabilitas akan tercapai jika pada perusahaan tersebut terjadi posisi dimana, posisi ROE tinggi dan posisi $\mathrm{BO} / \mathrm{PO}$ rendah. Ini terjadi karena perusahaan sudah meminimalkan biaya operasional dibandingkan dengan pendapatan operasional. Dari keseluruhan bank yang digunakan dalam penelitian dapat diketahui bahwa bank yang tingkat efisiensi cukup baik hanya berjumlah 5 bank yaitu Bank Lippo, Bank Internasional Indonesia, Bank negara Indonesia, Bank Central Asia, Bank Mandiri.

\section{PENUTUP}

Berdasarkan hasil penelitian yang telah dilakukan oleh penulis dengan menggunakan 21 bank yang Go Publik di Bursa Efek Jakarta, pada akhir tahun 2006 nilai solvabilitas tertinggi di miliki oleh Bank Rakyat Indonesia sebesar $25.22 \%$ diikuti oleh bank-bank lainnya. Namun ada beberapa Bank yang memiliki tingkat profitabilitas dibawah nol atau minus. Tingkat profitabilitasterendah terdapat pada Bank Eksekutif Internasioanal sebesar $11.80 \%$. Rasio solvabilitas dihitung menggunakan rasio Return on Equity(ROE). Rasio ini digunakan untuk perbandingan antara laba bersih dengan modal sendiri.

ROE merupakan indikator yang penting bagi para pemegang saham dan calon investor untuk mengukur kemampuan bank dalam memperoleh laba bersih yang terkait dengan pembiayaran deviden. Semakin besar ROE suatu bank, semakin besar pula tingkat keuntungan yang dicapai bank tersebut dan semakin baik pula posisi bank tersebut dari segi penggunaan asset. Dalam penelitian ini nilai rasio efisiensi dihitung dengan menggunakan rasio BO/PO (Beban Operasional dengan Pendapatan Operasional) yang digunakan untuk mengetahui berapa besar pendapatan operasional yang dapat dimanfaatkan bank agar dapat menekan / meminimalkan biaya operasional, sehingga dapat memberikan gambaran efisiensi suatu bank dengan kata lain dapat digunakan untuk mengukur kinerja manajemen suatu bank dalm menggunakan semua faktor produksinya dengan tepat guna dan hasil guna. Dalam rangka penilaian kesehatan bank umum, (Metode CAMEL) BI memberi nilai bobot sebesar 5\%. Karena Beban Operasional suatu bank. Sehingga bank memiliki efisiensi yang baik.

Sedangkan nilai Capital Adequacy Rasio (CAR), rasio ini harus berada diatas rata-rata CAR yang ditentukan oleh BI yaitu $\geq 8 \%$, namun diusahakan jangan terlalu jauh diatas $8 \%$ karena akan berdampak pada bagian modal yang digunakan untuk berjaga-jaga menjadi terlalu banyak. Tahun 2004 Bank dikatakan sehat sebanyak 10 bank yaitu Bank yaitu Bank Niaga, Bank Permata, Bank Mega, Bank NISP, Bank Eksekutif Internasioanal, Kesawan, Victoria Internasional, Bank Mayapada Internasional, Bank Bumiputera Indonesia dan Bank Nusantara Parahyangan. Sedangkan sisanya 11 bank memiliki tingkat rasio CAR jauh diatas rata-rata yang ditetapkan Bank Indonesia yaitu $\geq 8 \%$.

Hal ini disebabkan karena banyaknya dana yang menganggur 
sehingga tidak produktif. Banyaknya dana yang menganggur juga mengakibatkan penurunan tingkat profitabilitas perusahaan.

Berdasarkan hasil estimasi regresi diketahui bahwa nilai koefisien determinasi (R-Square) sebesar 0.793531 artinya kinerja keungan relatif baik, hal ini ditandai dengan membaiknya kinerja keuangan Bankbank yang Go Publik di Bursa Efek Jakarta tahun 2004-2006. Lembaga keuangan perbankan menjadi penguasa utama sector keuangan hingga saat ini. Di dunia Perbankan, sector perbankan masih harus berjuang memperbaiki kinerja dalam dunia perbankan, terutama memperbaiki kinerja kreditnya dengan memiliki manajemen kredit yang terencana.

\section{DAFTAR PUSTAKA}

Abdullah, Faisal M. 2004. Dasar- Dasar Manajemen Keuangan. UMM Press. Malang.

Abdullah, Faisal M. 2005. Manajemen Perbankan. UMM Press. Malang.

B. Sunartojo. 1982. Modal Kerja. Penerbit Balai Aksar. Jakarta.

Dendawijaya. Lukman. 2005. Manajemen Perbankan. Bumi Aksara. Jakarta.

Gujarati. Damodar. 1978. Ekonometrika Dasar. Terjemahan Sumarno Zain dalam

Gunawan Hutauruk (Ed). Jakarta: Erlangga.

Hasibuan. Malayu S.P. 2001. Dasardasar Perbankan. Bumi Aksara. Jakarta.
Helfert, Erick A. 1997. Teknik Analisa Keuangan. Erlangga. Jakarta.

Manurung. Mandala dan Rahardja. Prathama. 2004. Uang Perbankan dan Ekonomi Moneter. Fakultas Ekonomi UI. Jakarta.

Prastowo D. Dwi. 1995. Analisis Laporan Keuangan : Konsep dan Aplikasi. Edisi Pertama. Cetakan pertama. Yogyakarta: UPP AMP YKPN.

Siamat. Dahlan. 2005 . Manajemen Lembaga Keuangan, Kebijakan Moneter dan Perbankan. Edisi Pertama. Lembaga Penerbit Fakultas Ekonomi Universitas Indonesia.

Taswan. 1997. Akuntansi Perbankan. UPP AMP YKPN. Yogyakarta.

Team Laboratorium Ekonomi dan Studi Pembangunan. Oktober 2006. Modul Praktikum Ekonometrika. Edisi VIII. Fakultas Ekonomi UMM.

Widarjono. Agus. 2005. Ekonometrika “ Teori dan Aplikasi ". Ekonisia Fakultas Ekonomi UII Yogyakarta. 
